DOI: https://doi.org/10.32663

\title{
PUPUK ORGANIK CAIR DARI AIR LIMBAH LELE SISTEM BIOFLOK HASIL FERMENTASI AEROB DAN AN AEROB
}

\author{
(Liquid Organic Fertilizer From Lele Waste Bioflock System From Aerob and Anaerob \\ Fermentation) \\ Dedi Pardiansyah $^{1 *}$, Nasir Ahmad ${ }^{1}$, Firman ${ }^{1}$, Suharun Martudi ${ }^{1}$ \\ ${ }^{I}$ Program Studi Budidaya Perairan, Fakultas Pertanian Universitas.Prof. Dr. Hazairin, SH Bengkulu \\ Jalan Jend. Soedirman No. 184 Bengkulu \\ "Corresponding Author, Email: dedi2301@gmail.com
}

\begin{abstract}
The biofloc system catfish wastewater is in the form of accumulation of organic residues from feed residues, catfish manure, feed particles and bacteria and algae, because the biofloc catfish cultivation wastewater can be processed into organic fertilizer especially liquid organic fertilizer. The study used a completely randomized single factor treatment with an aerobic (A) fermentation process and Anaerobic fermentation process (B). Each treatment was repeated 8 times to obtain 16 experimental units. Furthermore, the results of the study data were analyzed by variance at the level of 5 percent. The results showed that the growth rate of catfish was very good. Where growth continues to increase the 10th day observation until the end of the study. While the content of $N, P$ and $K$ in the POC produced did not show a significant difference between POC fermented by Aerob and Anaerob. POC content fermented by Aerob; $N=1.645, P=0.326$ and $K=1.143$ while Anaerobic fermentation; $N=2.189, P=0.278$ and $K=1.165$.
\end{abstract}

Keywords: biofloc, catfish cultivation waste, POC

\begin{abstract}
ABSTRAK
Air limbah budidaya lele sistem bioflok di dalamnya berupa akumulasi residu organik yang berasal dari sisa pakan, kotoran lele, partikel-partikel pakan serta bakteri dan alga, karna itu air limbah budidaya ikan lele sistem bioflok dapat diolah menjadi pupuk organik khususnya pupuk organik cair. Penelitian menggunakan Rancangan Acak Lengkap faktor tunggal dengan perlakuan adalah proses fermentasi secara Aerob (A) dan proses fermentasi secara Anaerob (B). Tiap perlakuan diulang sebanyak 8 kali sehingga diperoleh 16 unit percobaan. Selanjutnya Data hasil penelitian dianalisis dengan sidik ragam pada taraf 5 persen. Hasil penelitian menunjukkan bahwa laju pertumbuhan ikan lele sangat baik. Di mana pertumbuhan terus meningkat sekat pengamatan hari ke-10 hingga akhir penelitian. Sedangkan kandungan N, P dan K didalam POC yang dihasilkan tidak menunjukkan perbedaan yang nyata antara POC yang difermentasi dengan cara Aerob dan Anaerob. Kandungan POC yang difermentasi dengan cara Aerob; $N=1,645$, $P=0,326$ dan $K=1,143$ sedangkan yang difermentasi secara Anaerob; $N=2,189, P=$ 0,278 dan $K=1,165$.
\end{abstract}

Kata kunci: bioflok, Limbah budidaya lele, POC 
DOI: https://doi.org/10.32663

\section{PENDAHULUAN}

Budidaya ikan lele sistem bioflok merupakan usaha budidaya ikan lele dengan padat tebar tinggi, penggunaan jumlah pakan yang tinggi, penambahan aerase dan penggantian air secara berkala dalam jumlah besar serta menghasilkan air limbah yang besar pula. Air limbah budidaya lele sistem bioflok di dalamnya berupa akumulasi residu organik yang berasal dari sisa pakan, kotoran lele, partikel-partikel pakan serta bakteri dan alga. Air limbah budidaya ikan lele sistem bioflok telah coba dimanfaatkan untuk budidaya cacing sutera (Pardiansyah, 2014), sedangkan menurut Firman et all. (2015), air limbah budidaya lele sistem intensif dapat diolah menjadi pupuk organik khususnya pupuk organik cair.

Produksi lele negara kita diperkirakan pada tahun 2014 diperkirakan mencapai 900 ribu ton. Produksi tersebut meningkat sangat tinggi yaitu sebesar 450 persen jika dibandingkan produksi lele tahun 2009 (KKP, 2010). Peningkatan produksi yang sangat tinggi tersebut tentunya dibarengi pula air limbah yang dihasilkan. Besarnya potensi air limbah budidaya lele sangat besar tersebut sayangnya belum dimanfaatkan secara optimal bahkan sering dijumpai pembudidaya lele masih membuang begitu saja air limbah tersebut disekitar pemukiman.

\begin{tabular}{crrr}
\multicolumn{2}{c}{ Budidaya } & sistem & bioflok \\
merupakan sistem & budiaya & yang
\end{tabular}
memanfaatkan bakteri heterotrof sebagai dekomposer di perairan. Bakteri heterotrof dapat mengubah nitrogen diperairan terutama amonia menjadi biomasa bakteri dan plankton dengan penambahan sumber karbon organik ke dalam media
budidaya.(Crab et al.2007). Nitrogen dalam perairan yang dihasilkan oleh limbah budidaya akan mengalami proses secara biologis yang menyerap amonium menjadi biomasa bakteri dengan penambahan sumber karbon organik (Pardiansyah, 2014).

Pemanfaatan nitrogen yang ada diperairan akan meningkatkan kualitas perairan pada wadah budidaya, selain itu flock yang terbentuk dapat juga dimanfaatkan sebagai pakan tambahan bagi jenis ikan lainnya seperti, ikan nila, tambakan dan ikan-ikan pemanfaat ditritus lainnya. Air hasil budidaya sistem bioflok mengandung banyak bahan organik khususnya kandungan $\mathrm{N}$ yang tinggi (pardiansyah. 2014). Kandungan N yang terdapat pada air budidaya ini dapat dimanfaatkan sebagai pupuk pada tanaman.

Pupuk organik dapat berupa padat maupun cair yang terbuat dari bahan organik yang berasal dari hewan dan atau tanaman maupun dari limbah pertanian yang telah terdekomposisi dengan bantuan decomposer. Pupuk organik berasal dari bahan organik yang di dalamnya kaya akan protein, karbohidrat dan lemak (Novizan, 2001). Senyawa organik ini diubah oleh mikroba menjadi senyawa anorganik yang penting sebagai penyedia hara bagi tanaman. Menurut Andriyeni et al., (2014), Air Limbah budidaya lele mengandung hara makro yang dibutuhkan tanaman. Kadar hara yang terkandung di dalam pupuk organik Cair dari air limbah budidaya lele sistem intensif berkisar 0,06-0,62 \% (Corganik), 0,49-1,32 \% (Nitrogen), ), 060,35\% (Phosfat), 0,22-4,97\% (kalium) dan pH 5,67-8,00 (Firman, 2016).

Pupuk organik yang terbentuk secara alami membutuhkan waktu 6 bulan. 
Hal ini sangat tergantung dari bahan dasar dari pupuk organik tersebut. Dekomposer berfungsi mempercepat proses dekomposisi bahan organik tersebut menjadi bhan anorganik. Di pasaran banyak dijumpai merek dekomposer yang pedagang seperti EM-4, Biosca, Stardec, Starbio dan lain sebagainya.

\section{BAHAN DAN METODE}

Penelitian dilaksanakan di Laboratorium Fakultas Pertanian Universitas Prof. Dr. Hazairin, SH Bengkulu pada Bulan Januari sampai September 2018. Alat yang digunakan adalah drum plastik sedang/box plastik, dirigen 20 liter, ember, aerator, selang aerator, batu aerator, centong, corong plastik, kamera, timbangan 200 g, gelas ukur, tangguk ikan, Adapun bahan yang digunakan adalah Ikan Lele, pakan pellet, limbah budidaya Lele, kapur pertanian, molllase dan dekomposer EM-4, alat tulis kantor.

Penelitian menggunakan Rancangan Acak Lengkap faktor tunggal dengan perlakuan adalah proses fermentasi secara Aerob (A) dan proses fermentasi secara Anaerob (B). Tiap perlakuan diulang sebanyak 8 kali sehingga diperoleh 16 unit percobaan. Selanjutnya Data hasil penelitian dianalisis dengan sidik ragam pada taraf 5 persen.

\section{Tahapan Pelaksanaan}

a. Tahap 1 (Budidaya Lele Sistem Bioflok)

1. Menyiapkan drum plastik sedang/ atau boks plastik sedang sebanyak 8 buah, lalu di isi air setinggi 30-40 cm. Selanjutnya tiap drum diberi aerator.

2. Penumbuhan flok dengan cara menambahkan mollase ke dalam wadah budidaya/drum sebanyak 5 gram perwadah budidaya(drum), kemudian dibiarkan 5-7 hari.

3. Penebaran benih lele ukuran 6-8 dengan padat tebar $250 \mathrm{ekor} / \mathrm{m}^{2}$

4. Pemberian pakan pellet dengan dosis 5 persen dari biomassa ikan. Pemberian dilakukan dengan frekuensi 3 kali sehari, dengan pakan sore/malam hari lebih dibanding siang hari.

5. Penambahan mollase ke wadah budidaya dilakukan dengan memperhatikan jumlah pakan yang diberikan. Perbandingan antara mollase (Karbon) dan jumlah pakan (Nitrogen) diusahakan sebesar 20

6. Pengamatan pertumbuhan ikan dilakukan tiap 10 hari sekali. Bersamaan dengan pemberian jumlah pakan disesuaikan dengan berat biomassa ikan.

7. Panen ikan lele dilakukan setelah berat ikan berkisar 125 -150 gram.

\section{b. Tahap 2 (Pembuatan pupuk organik Cair)}

1. Menyiapkan dirigen 20 liter sebanyak 16 buah, kemudian diberi label perlakuan A (fermentasi secara aerob) dan B (fermentasi secara anaerob). Tiap perlakuan diulang sebanyak 8 kali.

2. Mengisi dirigen 20 liter dengan air limbah (hasil tahap 1) sebanyak 10 20 liter. Selanjutnya tambahkan dekomposer dan mollase. Perbandingan air limbah : dekomposer : $50: 1: 1$. Kemudian diaduk merata. Selanjutnya lakukan pemasangan aerator pada perlakuan fermentasi secara aerob(A), 
3. sedangkan pada perlakuan fermentasi secara anaerob(B) dirigen ditutup rapat. Bila $\mathrm{pH}$ larutan terlalu rendah tambahkan kapur pertanian hingga $\mathrm{pH}$ larutan mencapai 7-8.

4. Biarkan larutan fermentasi selama 15-20 hari atau sampai pupuk organik cair terbentuk. Ciri pupuk organik telah jadi bila pada permukaan larutan terjadi proses pembentukan buih atau terbentuknya butiran putih pada permukaan larutan.

5. Mengambil sampel pupuk organik cair untuk dianalisis kadar nitrogen, phosfat, kalium, $\mathrm{pH}$ dan $\mathrm{C}$ organik.
Kemudian sampel larutan dibawa ke laboratorium.

\section{HASIL DAN PEMBAHASAN}

Setelah melaksanakan budidaya ikan lele selama 60 hari diperoleh hasil Seperti pada Gambar 1. Berdasarkan gambar 1, dapat dilihat bahwa laju pertumbuhan ikan lele sangat baik. Di mana pertumbuhan terus meningkat sekat pengamatan hari ke-10 hingga akhir penelitian.

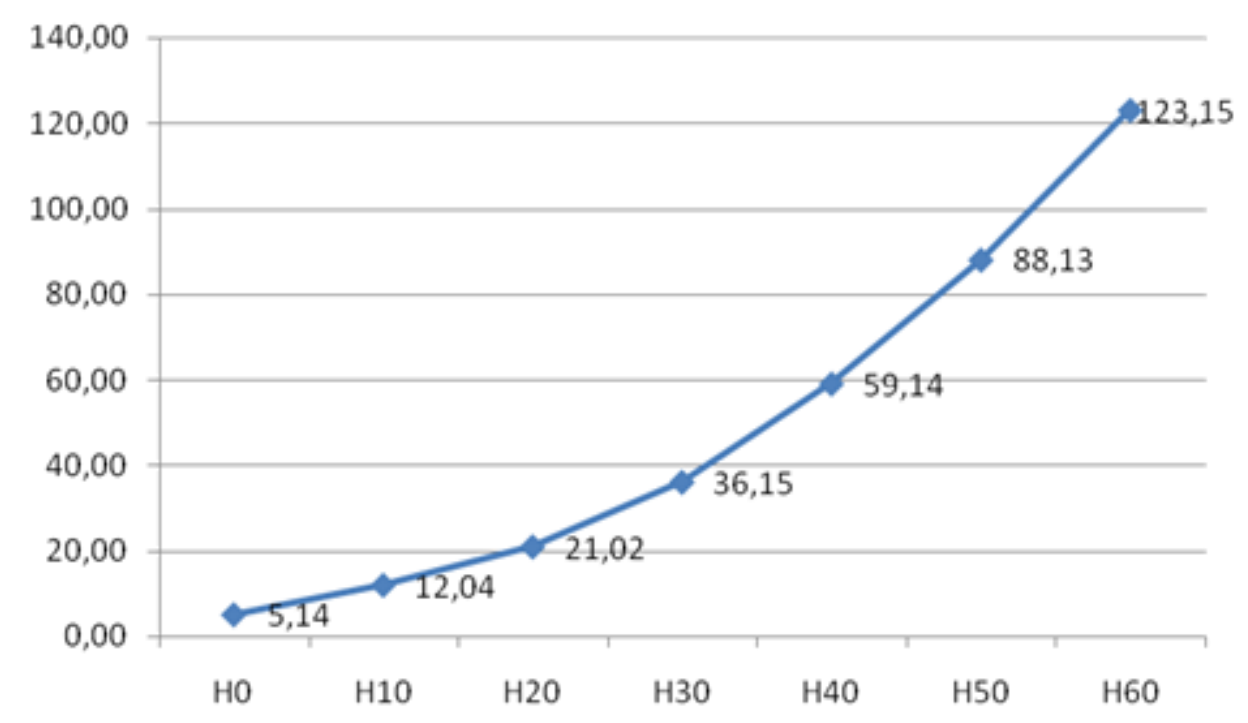

Gambar 1. Laju pertumbuhan ikan lele dumbo

Air limbah budidaya ikan lele sistem bioflok selajutnya di fermentasi dengan dua cara yakni secara Aerob dn An aerob selama 20 hari. Hasil fermentasi yang telah difermentasi dianalisis kadar nitrogen, kalium, phospat, $\mathrm{pH}$ dan $\mathrm{C}$ organik seperti pada Tabel 1. 
Tabel 1. Hasil Analisa Keragaman Kandungan N, P dan K pada POC

\begin{tabular}{llc}
\hline Variabel pengamatan & Nilai F. hitung & Nilai F tabel (5\%) \\
\hline Nitrogen & 2,957 & $4,60 \mathrm{~ns}$ \\
Phospor & 1,949 & $4,60 \mathrm{~ns}$ \\
Kalium & 0,086 & $4,60 \mathrm{~ns}$ \\
\hline
\end{tabular}

Keterangan: berbeda tidak nyata

Berdasarkan hasil analisa

limbah budidaya iken lele yang di keragaman di atas menunjukkan bahwa tidak ada perbedaan yang nyata antara kandungan $\mathrm{N}$, $\mathrm{P}$, dan $\mathrm{K}$ terhadap proseses fermentasi secara aerob dan anaerob. Namun untuk untuk lebih jelasnya nilai kandungan $\mathrm{N}, \mathrm{P}$ dam $\mathrm{K}$ dari $\mathrm{POC}$ dapat dilihat pada Gambar 2.

Kandungan N, P dan K pada POC limbah budidaya lele sistem bioflok yang di fermentasi dengan Aerob maupun An Aerob lebih baik jika dibandingkan denga POC dari bahan lainnya seperti POC dari Limbah serasa dengan inokulan kotoran sapi (Hapsari, 2013), POC limbah ikan mujair (Lepongbulan 2017), POC urine sapi (Khoirul 2013), POD dari sludge instalasi gas bio dengan penambahan tepung tulang ayam dan tepung darah sapi (Capah, 2006), POC dari limbah sayur (Sarjono, 2013). budidayakan dengan sistem bioflok. Ikan lele hanya memanfaatkan $20-30 \%$ pakan untuk penambahan biomassanya (pardiansyah 2015), ini berarti 79-80\% dari pakan yang di manfaatkan ikan terbuang melalui pases dan urin ikan. N,P dan K yang berasal dari fases dan urine ikan lele dimanfaatkan oleh bakteri untuk membentuk biomassa bakteri dalam bentuk gumpaan dengan bantuan carbon dan penambahan oksigen (Pardiansyah 2014). Gumpalan bakteri dan mikroorganisme inilah yang kemudian di fermentasi menjadi POC. Dengan kandungan N, P dan K yang cukup tinggi POC limbah budidaya ikan lele sistem biflok ini tentu sangat dianjurkan untuk dimanfaatkan sebagai pupuk tanaman pangan maupun tanaman lainnya.

Tingginya kandunga N, P dan $\mathrm{K}$ berasal dari akumulasi bahan organik

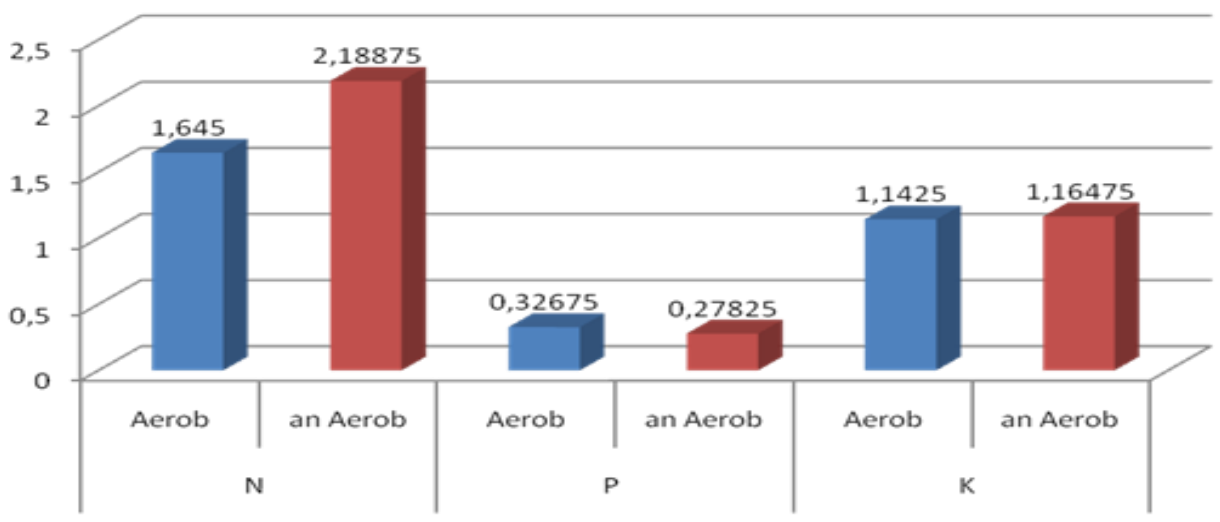

Gambar 2. Hasil Analisa N, P dan K (\%) yang terkandung didalam POC Limbah Budidaya Lele sistem Bioflok 


\section{KESIMPULAN}

Budidaya ikan lele dengan sistem bioflok menunjukan pertumbuhan yang sangat baik. Kandungan N, P dan K pada limbah budidaya ikan lele yang difermentasikan menggunakan sistem aerob dan an aerob memiliki hasil yang cukup baik dan dapat langsung diteBarkan pada kolam maupun tanaman.

\section{DAFTAR PUSTAKA}

Andriyeni, Firman dan Nurseha, 2014. Studi Potensi Limbah Budidaya lele sebagai Bahan Utama Pembuatan Pupuk Organik. Laporan penelitian, Lembaga Penelitian dan Pengabdian Universitas Prof. Dr. Hazairin, SH. Bengkulu.

Capah R.L. 2006. Kandungan Nitrogen Dan Fosfor Pupuk Organik Cair Dari Sludge Instalasi Gas Bio Dengan Penambahan Tepung Tulang A Yam DanTepung Darah Sapi. SKRIPSI. Institut Pertanian Bogor.

Crab R., Avnimelech, Y., Defoirdt, T., Bossier, P., Verstracte, W. 2007. Nitrogen removal techniques ini aquaculture for sustainable production. Aquaculture, 270: 1-14

Firman, Yulfiperius, Andriyeni. 2015. Air Limbah Budidaya lele Sebagai Bahan Baku Pupuk Organik; Upaya meningkatan Pendapatan Pembudidaya Lele dan Mendukung Go Organik. Laporan penelitian Hibah Bersaing. Universitas Prof. Dr. Hazairin, SH. Bengkulu. 50 halaman).
Firman, 2016. Pupuk Organik Cair (POC) Air Limbah Budidaya lele (ALBL). Fakultas Pertanian(Leaflet).

Khoirul, M.H. 2013. Pembuatan Pupuk Organik Cair Dari Urin Sapi Dengan Aditif Tetes Tebu (Molasses) Metode Fermentasi SKRIPSI Universitas Negeri Semarang.

Lepongbulan, W, Vanny, M.A Tiwow, Anang Wahid, M. Diah. 2017. Analisis Unsur Hara Pupuk Organik Cair Dari Limbah Ikan Mujair (Oreochromis Mosambicus) Danau Lindu Dengan Variasi Volume Mikroorganisme Lokal (Mol) Bonggol Pisang. J. Akad. Kim. 6(2): 92-97. Palu

Pardiansyah, D, Eddy Supriyono, Daniel Djokosetianto. 2014. Evaluation of integrated sludge worm and catfish farming with biofloc system. Jurnal Akuakultur Indonesia 13 (1), 28-35.

Pardiansyah, D. 2015. Meminimalisir Limbah Nitrogen Dalam Budidaya Ikan Lele (Clarias Sp.) Dengan Budidaya Sistem Bioflok. Jurnal Agroqua Vol. 13 No.1.

Sarjono, E.S. Edu Surya, Netti Herlina. 2013. Pembuatan Pupuk Cair Dan Biogas Dari Campuran Limbah Sayuran. Jurnal Teknik Kimia USU, Vol. 2, No. 3

Yekti, A.H. 2013. Kualitas Dan Kuantitas Kandungan Pupuk Organik Limbah Serasah Dengan Inokulum Kotoran Sapi Secara Semi anaerob. Nakah Publikasi Universitas Muhammadiah Jakarta. 